\title{
Phagotrophic nanoflagellates contribute to occurrence of $\alpha$-glucosidase and aminopeptidase in marine environments
}

\author{
Markus Karner, Christine Ferrier-Pagès*, Fereidoun Rassoulzadegan
}

CNRS-URA 716, Station Zoologique, BP 28, F-06230 Villefranche-sur-Mer, France

\begin{abstract}
Using fluorogenic substrate analogs, the dynamics of extracellular enzyme activities (EEA) of free and particle-bound $\alpha$-glucosidase and aminopeptidase were investigated in mixed cultures of marine phagotrophic nanoflagellates and bacteria. Flagellate growth on either live or heatkilled bacteria led to an expression of free aminopeptidase activity with up to $94 \%$ of total EEA found in the dissolved phase. No significant release of free $\alpha$-glucosidase or free aminopeptidase was found in flagellate-free bacterial cultures. Fed with heat-killed bacteria, flagellates seemed to exhibit both cell wall bound $\alpha$-glucosidase and aminopeptidase activities. Flagellate biovolume-specific EEA in flagellate assemblages grown on heat-killed bacteria was similar in magnitude to bacterial biovolumespecific EEA in flagellate-free bacterial cultures. The significance of these results is further discussed according to current theories on enzyme-catalyzed organic matter cycling.
\end{abstract}

KEY WORDS: Extracellular enzyme B Bacteria P Protozoa · Organic matter cycling

\section{INTRODUCTION}

Extracellular enzyme activity in marine environments has attracted increasing attention of oceanographers since the work of Hoppe (1983), who introduced the use of fluorogenic substrates. While many studies in the past focused on the measurement of enzyme activity in untreated, whole water samples, it is also possible to distinguish between apparently free (detectable in sub-micrometre filtrate) and particlebound enzyme activity. Hoppe (1983) reported that the most important proportion of enzyme activity in the sea is found in the bacterial size range. Hollibaugh \& Azam (1983) and Vives Rego et al. (1985) found only $0.2 \%$ and 0 to $30 \%$ of the proteolytic activity of seawater in the $<0.2 \mu \mathrm{m}$ fraction, respectively. Similar results have been obtained by Rosso \& Azam (1987). It has therefore been widely assumed that extracellular glucosi-

\footnotetext{
*Present address: Observatoire Océanologique Européen, Musée Océanographique, Avenue Saint Martin, MC-98000 Monaco
}

dases and aminopeptidases in the marine environment are almost exclusively bound to bacterial cell walls.

Dissolved enzyme activity, however, seems to constitute a significant fraction of either total glucosidic or proteolytic activity in both marine snow and bulk phase seawater (Karner \& Herndl 1992). Free exohydrolases with low hydrolysis-uptake coupling are thought to be produced by particle-colonizing bacteria (Azam \& Smith 1991). Smith et al. (1992) found both a high proteolytic activity on marine snow and an important release of amino acids from marine snow. These findings suggest a low hydrolysis-uptake coupling, expected from the action of free enzymes. Somville \& Billen (1983) and Karner \& Rassoulzadegan (unpubl.) observed a high proportion of proteolytic activity in the $0.2 \mu \mathrm{m}$ filtrate in pelagic samples, and high permanent proportions of both glucosidase and peptidase activities in the dissolved phase, regardless of the occurrence of marine snow.

Other mechanisms than bacterial particle colonizing, potentially responsible for free extracellular enzyme activities, must therefore be considered. Among alter- 
native pathways are the release of substantial amounts of free hydrolases by free-living bacteria while growing under specific nutrient conditions, and enzyme release by phagotrophic protozoans. Recent studies show evidence for protozoan-specific extracellular enzyme activity. Nagata \& Kirchman (1992) and González et al. (1993) found occurrence of flagellate digestive enzymes in marine flagellate cultures. Using fluorogenic substrate analogs, Vrba et al. (1993) related protistan grazing activities to $\beta$-glucosaminidase activities. General hydrolases, such as $\alpha$-glucosidase and aminopeptidase, that cover a wide range of potential substrates might also be mediated by protozoan activity. Those hydrolases are ubiquitous in marine environments (Chróst 1990). $\alpha$-glucosidase and aminopeptidase catalyze the degradation of $\alpha$-glucosidic and peptide-like bonds, respectively. The activities of these enzymes therefore represent key parameters in microbial degradation of organic matter in marine environments.

In this study, we compared the mechanisms of occurrence of free and particle-bound $\alpha$-glucosidase and leucine-aminopeptidase activities in both cultures of marine bacteria and phagotrophic marine nanoflagellates grown on live and heat-killed bacteria.

\section{MATERIALS AND METHODS}

Using Niskin bottles, sea water was sampled from $10 \mathrm{~m}$ depth in the Ligurian Sea (northwestern Mediterranean) at either Point B (a standard mesooligotrophic oceanographic station off Villefranchesur-Mer, France, $43^{\circ} 41^{\prime} 10^{\prime \prime}$ N, $7^{\circ} 19^{\prime} 0^{\prime \prime}$ E) or Stn 1, an oligotrophic station 28 miles offshore $\left(43^{\circ} 24^{\prime} 42^{\prime \prime} \mathrm{N}\right.$, $7^{\circ} 52^{\prime} 18^{\prime \prime} \mathrm{E}$ ). Microorganisms were removed by filtering the samples through a $0.22 \mu \mathrm{m}$ Millipore ${ }^{\mathrm{TM}}$ GS filter $(<100 \mathrm{mbar}$ vacuum). Aliquots of $0.22 \mu \mathrm{m}$ filtrate were enriched with wheat grains according to Rivier et al. (1985). Bacterial cultures were obtained by inoculation of a few drops of $0.4 \mu \mathrm{m}$ filtrate $(3$ successive filtrations through Nuclepore ${ }^{\mathrm{TM}}$ membrane filters, no vacuum applied) from the same sample in the above enriched $0.22 \mu \mathrm{m}$ filtrates. Two sets of bacterial cultures with different enrichment levels were prepared. In culture 'BE', the bacteria were obtained in mesooligotrophic coastal waters from Point $B$ and enriched with ca 10 wheat grains in $700 \mathrm{ml}$ culture medium. In culture ' $\mathrm{BO}$ ', the bacteria were obtained in seawater sampled at the oligotrophic Stn 1, and enriched with a single wheat grain in $700 \mathrm{ml}$ culture medium.

Naturally occurring phagotrophic flagellate cultures were prepared by inoculation of a $5 \mu \mathrm{m}$ filtrate ( 3 successive filtrations, Nuclepore ${ }^{T M}$ membrane filters, no vacuum applied) of the same above samples in bacter- ial suspensions prepared in a similar way as the BE cultures. The bacteria were either live ('FL') or previously heat-killed ('FHK'). Heat-killed bacteria were obtained according to Ferrier-Pagès \& Rassoulzadegan (1994). Live and heat-killed bacterial cultures were both filtered through $4 \mu \mathrm{m}$ Nuclepore ${ }^{\mathrm{TM}}$ polycarbonate filters to remove bacterial aggregates prior to the flagellate inoculation. The absence of metabolizing bacteria in the heat-killed suspension (no significant changes in bacterial abundance) was checked daily in control bottles during the experiment. Prior to enzyme activity experiments with heat-killed bacterial media, phagotrophic flagellates were already grown for several generations on the same heat-killed bacterial prey in order to avoid carry-over of live bacteria to the experimental bottles. All cultures were run in triplicate and incubated in the dark at $20^{\circ} \mathrm{C}$. Time zero is the time of inoculation of microorganisms.

Microscope counts. Subsamples of the cultures were fixed with buffered formalin ( $2 \% \mathrm{v} / \mathrm{v}$ final conc.). Bacteria and flagellates were counted according to Porter \& Feig (1980) under a Zeiss Axiophot epifluorescence microscope equipped with a $100 \times$ Plan-Neofluar objective.

Extracellular enzyme activitiy (EEA). To measure EEA, samples taken from the cultures were divided into 2 aliquots, untreated and $0.1 \mu \mathrm{m}$ filtered. To avoid potential organic contaminations by rubber stoppers, we used filtration units exclusively made of glass. Furthermore, $0.1 \mu \mathrm{m}$ Durapore ${ }^{\mathrm{TM}}$ filters (Millipore, Inc., $<100$ mbar vacuum) were used to avoid chemical transformations of the filtrate. Indeed, Durapore ${ }^{\text {TM }}$ filters are chemically inert and exhibit very low protein retention coefficients and low surfactant addition (purchaser's information). Glassware used in the experiment was precombusted at $500^{\circ} \mathrm{C}$ for $4 \mathrm{~h}$ before use. Fluorogenic substrates were used to estimate EEA (Hoppe 1983) in untreated subsamples as well as in the $0.1 \mu \mathrm{m}$ filtrate. We used the substrate analogs 4 -methyl umbelliferyl $\alpha$-D-glucopyranoside ( $\alpha$-MUF) and l-ieucine 7 -amido-4-methyl coumarin (or l-leucine 4 -methyl-7-coumarinylamide, leu-MCA) to estimate potential hydrolysis rates of glucosidic and peptidic bonds, respectively. 4-methylumbelliferone (MUF) and 7 -amino-4-methylcoumarin (MCA) were used as standards for $\alpha$-MUF hydrolysis and leu-MCA hydrolysis, respectively. Fluorogenic substrates and standards were purchased from Sigma, Inc. Untreated and $0.1 \mu \mathrm{m}$ filtered aliquots were transferred to disposable test tubes (Falcon, Inc.) where either $\alpha$-MUF or leu-MCA were added at final concentrations of 100 and $50 \mu \mathrm{M}$, respectively. We have found these concentrations to yield maximum hydrolysis rates when added to the naturally occurring microbial communities used for preparation of the cultures. Enzyme as- 
says were carried out at natural pH. Fluorescence in aliquots with substrate analogs was measured before and after incubation in the dark at $20^{\circ} \mathrm{C}$ for up to $1 \mathrm{~h}$. All fluorescence measurements were made in 3 replicate $2.5 \mathrm{ml}$ subsamples using a SPEX Fluorolog spectrofluorimeter at $360 \mathrm{~nm}$ excitation and $444 \mathrm{~nm}$ emission wavelengths. Increase in fluorescence over time was attributed to hydrolysis catalyzed by extracellular enzymes, total or free in untreated or $0.1 \mu \mathrm{m}$ filtrate aliquots, respectively. The difference between increase in fluorescence over time in untreated and in $0.1 \mu \mathrm{m}$ filtered aliquots was interpreted as hydrolysis catalyzed by extracellular enzymes bound to the cell walls of microorganisms (subsequently called particlebound enzymes). In order to convert increases in fluorescence to hydrolysis rates, MUF and MCA standard curves were established against a blank for untreated sample water as well as for the $0.1 \mu \mathrm{m}$ filtered aliquots at the beginning of each experiment. Hydrolysis rates of $\alpha$-MUF and leu-MCA will be referred to as $\alpha$-glucosidase and aminopeptidase activities, respectively, as it has been shown that $\alpha$-MUF and leuMCA hydrolysis are mediated by enzymes specific to $\alpha$-glucosidic and peptidic bonds, respectively (Somville 1984, Hoppe et al. 1988). We calculated bacteriaspecific enzyme activities in $B E$ and $B O$, dividing the particle-bound fraction of EEA by the bacterial biovolume present. Similarly, flagellate-specific enzyme activity was calculated in FHK only (in FL, such a calculation would be inappropriate due to the simultaneous presence of both live bacteria and flagellates). We used the biovolume conversion factors obtained in Point B waters by Rivier et al. (1985), i.e. 0.1 and $14 \mu^{3}$ for bacterial and flagellate cell volumes, respectively.

\section{RESULTS}

The results showed a clear difference in changes in bacterial abundance between the $\mathrm{BO}$ and $\mathrm{BE}$ assays. Three bacterial biomass peaks of $14.1 \pm 4.62,12.8 \pm$ 2.03 and $12.5 \pm 5.54 \times 10^{5} \mathrm{ml}^{-1}$ were observed in $\mathrm{BO}$ after 5, 11 and $18 \mathrm{~d}$ respectively (Fig. 1A), with marked decreases to $3.64 \pm 1.18$ and $4.97 \pm 1.19 \times 10^{5} \mathrm{ml}^{-1}$ following the 2 first peaks at Days 6 and 14 (Fig. 1A). Unless otherwise indicated, averages of 3 replicates $\pm \mathrm{SD}$ are given. Direct epifluorescence microscope observations revealed frequent changes in bacterial cell morphology, suggesting an unstable species composition. BE exhibited a more classical growth pattern with an exponential phase and a beginning stationary phase $\left(3.21 \pm 0.79 \times 10^{7} \mathrm{ml}^{-1}\right.$ at Day 22, Fig. 2A). However, at the end of experiment, bacterial numbers rose to $5.33 \pm 0.05 \times 10^{7} \mathrm{ml}^{-1}$.

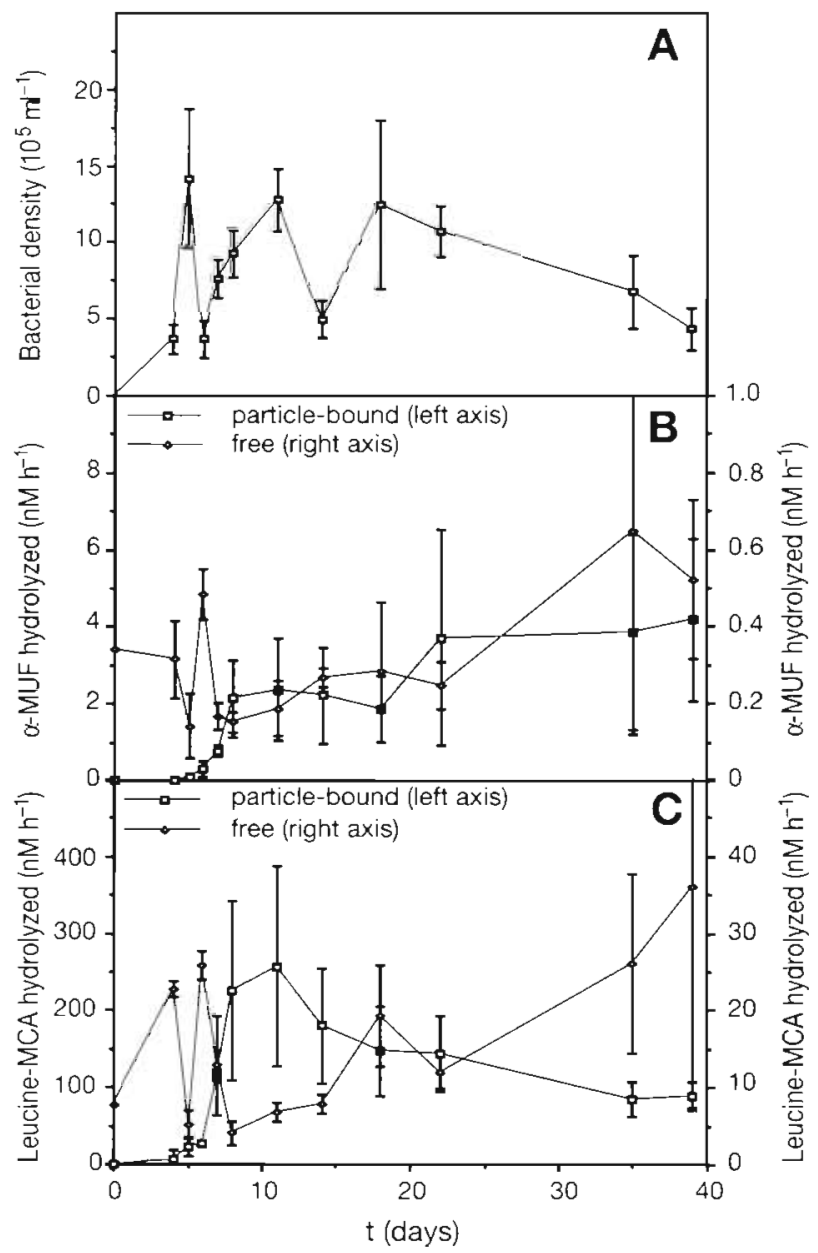

Fig. 1. Culture on wheat grain infusion of a mixed bacterial assemblage from pelagic origin (BO). (A) Bacterial density; (B) free and particle-bound extracellular $\alpha$-glucosidase activity; (C) free and particle-bound extracellular aminopeptidase activity. Note that free and particle-bound extracellular enzyme activities have different scales in (B) and (C). Enzyme activity represented is the hydrolysis rate of the respective fluorogenic substrate analog. Error bars: SD of 3 replicate experiments. For details see text

In both cultures with phagotrophic flagellates grown on live bacteria (FL) and heat-killed bacteria (FHK), nanoflagellate abundance reached 1 and 2 peaks, respectively, before declining. Massive declines in bacterial densities were observed in both assays. In FL, nanoflagellate abundance reached a first peak of $8.82 \pm 0.14 \times 10^{4} \mathrm{ml}^{-1}$ after $45 \mathrm{~h}$ incubation (Fig. 3A) with a decline and a second peak of $5.60 \pm 0.76 \times$ $10^{4} \mathrm{ml}^{-1}$ after $148 \mathrm{~h}$ incubation. In FHK, a flagellate peak $\left(13.9 \pm 5.86 \times 10^{4} \mathrm{ml}^{-1}\right)$ was obtained at $96 \mathrm{~h}$ (Fig. 4A).

Following an initial lag phase, particle-bound EEA in $\mathrm{BO}$ for both $\alpha$-glucosidase and aminopeptidase activities sharply increased between Days 6 and 7 . Particle- 


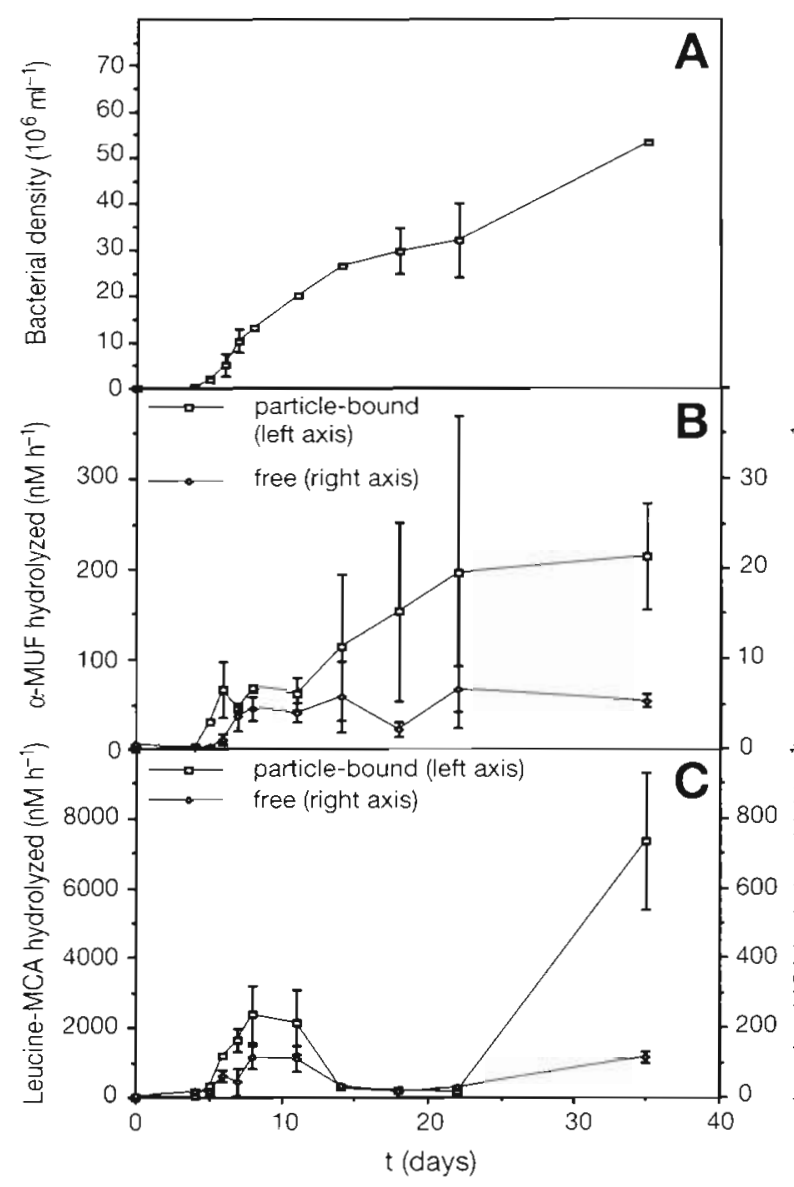

Fig. 2. Culture on wheat grain infusion of a mixed bacterial assemblage from near-coastal origin (BE). (A) Bacterial density; (B) free and particle-bound extracellular $\alpha$-glucosidase activity; (C) free and particle-bound extracellular aminopeptídase activity. Note that free and particle-bound extracellular enzyme activities have different scales in (B) and (C). Enzyme activity represented is the hydrolysis rate of the respective fluorogenic substrate analog. Error bars: SD of 3 replicate experiments. For details see text

bound $\alpha$-glucosidase EEA reached a stationary phase after $8 \mathrm{~d}$ (Fig. 1B), yielding its highest value at the end of the experiment $\left(4.16 \pm 2.12 \mathrm{nM} \mathrm{h}^{-1}\right)$. Particle-bound aminopeptidase EEA reached a single peak at Day 11 $\left(257 \pm 129 \mathrm{nM} \mathrm{h}^{-1}\right)$ followed by a steady decline (Fig. 1C).

In $B E$, particle-bound $\alpha$-glucosidase EEA followed the trend in the bacterial abundances and reached its highest value at Day $35\left(212 \pm 59.0 \mathrm{nM} \mathrm{h}^{-1}\right.$. Fig. 2B) whereas particle-bound aminopeptidase EEA reached a peak of $2376 \pm 823 \mathrm{nM} \mathrm{h}^{-1}$ at Day 8 (Fig. 2C), collapsing thereafter A single very high value was recorded at the end of the experiment $(7338 \pm 1957 \mathrm{nM}$ $h^{-1}$, Fig. 2C).

In FL, particle-bound $\alpha$-glucosidase and aminopeptdidase EEA both showed a decreasing tendency
(Fig. 3B, C) parallel to the decrease in bacterial density (Fig. 3A). Decreases in both EEA were from 171 to 27.4 $\pm 14.9 \mathrm{nM} \mathrm{h}^{-1}$ and from 1136 to $362 \pm 207 \mathrm{nM} \mathrm{h}^{-1}$ for particle-bound $\alpha$-glucosidase and particle-bound aminopeptidase, respectively.

Following the flagellate inoculation, particle-bound EEA in FHK increased rapidly and reached maximum values of $68.6 \pm 10.2$ and $1141 \pm 28.6 \mathrm{nM} \mathrm{h}^{-1}$ at Hour 53 for particle-bound $\alpha$-glucosidase and particle-bound aminopeptidase, respectively (Fig. 4B, C). Both peaks preceded that of the flagellate abundance.

Microbial biovolume-specific particle-bound EEA are given in Table 1 . The highest values per bacterial biovolume for $\alpha$-glucosidase and aminopeptidase in $\mathrm{BE}$ were obtained during the early exponential phase. In $\mathrm{BO}$, the highest values per bacterial biovolume

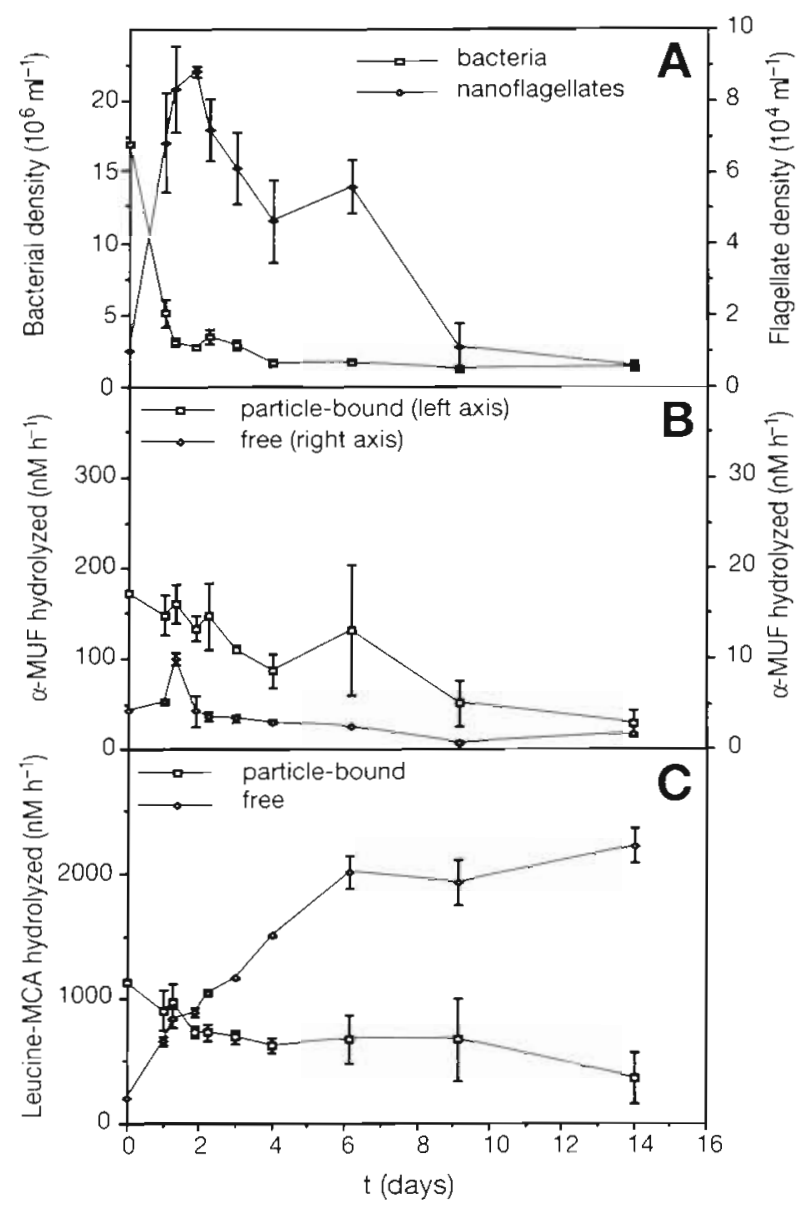

Fig. 3. Culture of phagotrophic nanoflagellates on live bacterial prey (FL). (A) Microbial density; (B) free and particlebound extracellular $\alpha$-glucosidase activity; (C) free and particle-bound extracellular aminopeptidase activity. Note that free and particle-bound extracellular enzyme activities have different scales in (B). Enzyme activity represented is the hydrolysis rate of the respective fluorogenic substrate analog. Error bars: SD of 3 replicate experiments. For details see text 


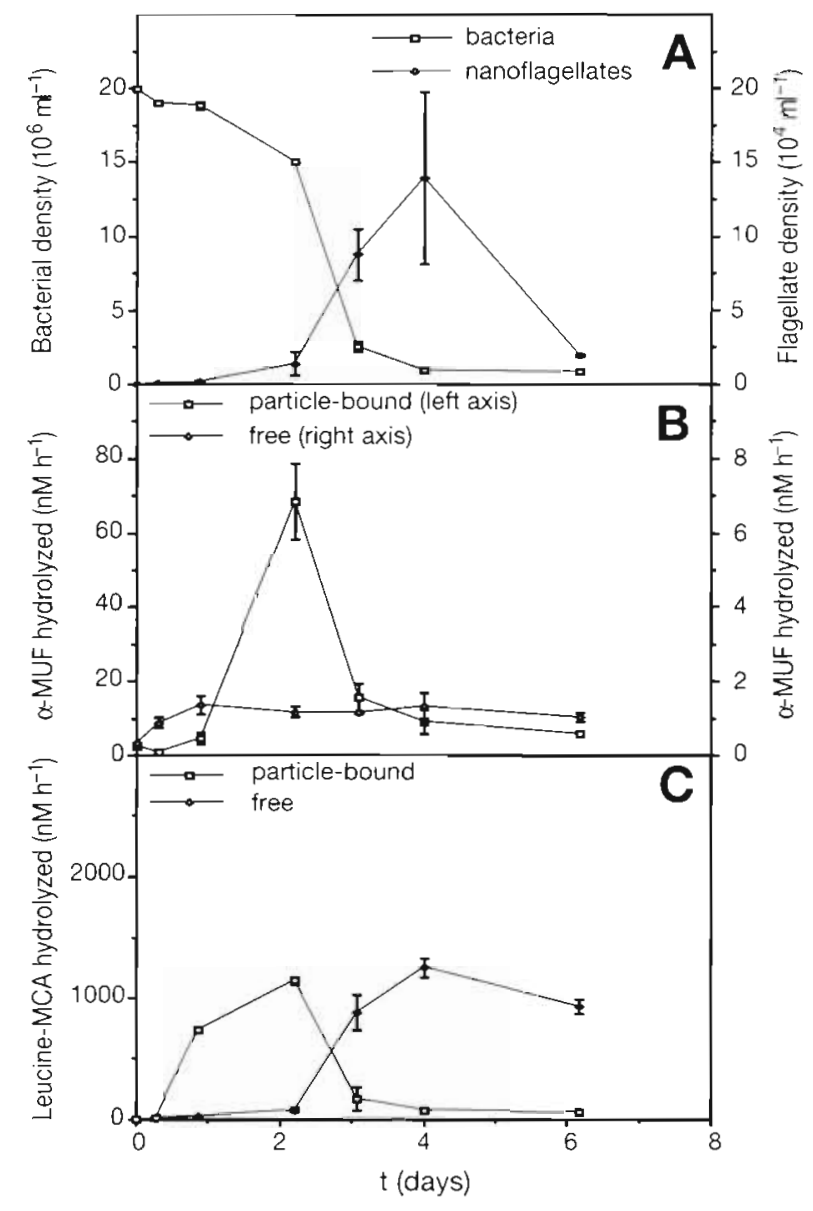

Fig. 4. Culture of phagotrophic nanoflagellates on heat-killed bacterial prey (FHK). (A) Microbial density; (B) free and particle-bound extracellular $\alpha$-glucosidase activity; (C) free and particle-bound extracellular aminopeptidase activity. Note that free and particle-bound extracellular enzyme activities have different scales in (B). Enzyme activity represented is the hydrolysis rate of the respective fluorogenic substrate analog. Error bars: SD of 3 replicate experiments. For details see text

were observed during the growth phases of the cultures for aminopeptidase, while those for $\alpha$-glucosidase increased until the end of the experiment. Specific particle-bound EEA per nanoflagellate biovolume, measurable only in FHK (see 'Materials and methods'), reached their highest levels during the beginning exponential phase and their lowest levels while reaching the peak and decaying (see Table 1 for ranges).

In $\mathrm{BO}$, residual free EEA was observed at the beginning of the experiment (Fig. 1B, C). However, once increases in culture-mediated EEA started (Day 7 for $\mathrm{BO}$ and Day 5 for BE, Figs. $\mathrm{B}, \mathrm{C} \& 2 \mathrm{~B}, \mathrm{C}$ ), values for free EEA were lower than those for particle-bound EEA. In BO after Day 7 , free $\alpha$-glucosidase and free aminopeptidase EEA ranged from 7.5 to $19 \%$ and from 2.6 to $26 \%$ of total EEA, respectively. In BE after Day 5 ,
Table 1. Ranges of extracellular enzyme activities per biovolume in cultures of assemblages of marine organisms. Data given are averages of 3 replicate cultures. Each range represents the minimum and the maximum of the respective enzyme activity encountered during the respective experiment. The variation factor is the minimum activity, divided by the maximum activity (rounded). Ranges are in $10^{-18} \mathrm{~mol} \mathrm{~h}^{-1}$ $\mathrm{mm}^{-3}$ fluorogenic substrate analog hydrolyzed. $\mathrm{BO}, \mathrm{BE}$ : bacteria grown on wheat grain infusion with low and high enrichments, respectively; FHK: phagotrophic nanoflagellates grown on heat-killed bacteria. For further details see text

\begin{tabular}{|cccc|}
\hline & $\mathrm{BO}$ & $\mathrm{BE}$ & FHK \\
\hline $\begin{array}{l}\text { Q-glucosidase } \\
\text { Range }\end{array}$ & $0.17-120$ & $30-170$ & $4.7-440$ \\
Variation factor & 710 & 5.7 & 94 \\
Aminopeptidase & & & \\
Range & $190-3800$ & $50-3000$ & $43-27000$ \\
Variation factor & 20 & 60 & 630 \\
\hline
\end{tabular}

free $\alpha$-glucosidase and free aminopeptidase EEA ranged from 0.3 to $7.4 \%$ and from 4.5 to $16 \%$ of total EEA, respectively.

In the FL, free $\alpha$-glucosidase EEA never exceeded $7 \%$ of total activity (Fig. 3B) while free aminopeptidase EEA showed a constant increase from $15 \%$ of total activity to $86 \%$ at the end of the experiment (Fig. 3C). This increase was sharpest during flagellate growth phase. In FHK, free $\alpha$-glucosidase remained below $16 \%$ after the first day. Free aminopeptidase EEA in FHK covaried with flagellate growth (Fig. 4A, C) and reached $94.3 \%$ of total activity at the end of the experiment.

\section{DISCUSSION}

An increasing number of studies concern estimations of extracellular glucosidase and aminopeptidase activities in aquatic environments (see Hoppe 1991). It has hitherto been assumed that in marine environments (1) these hydrolases are usually bound to the cell walls of microorganisms, and (2) heterotrophic bacteria are almost entirely responsible for the occurrence of these extracellular enzymes (Hoppe 1983, Vives Rego et al. 1985, Rosso \& Azam 1987, Chróst et al. 1989).

Enzymes measured in submicronic filtrates ('free enzyme activity') can potentially originate from truly dissolved enzymes secreted by microorganisms as a response to specific trophic situations, from enzyme secretion as a result of attachment of bacteria to particles, or from zooplankton grazing as a byproduct (e.g. protozoan food vacuole contents). However, enzymes passing submicronic filters might as well be enzymes 
bound to colloids or to sub-micrometre particles. The latter are ubiquitous in marine environments (Isao et al. 1990). Using ultracentrifugation, Vives Rego et al. (1985) showed that the 'free' enzyme activity (passing $0.2 \mu \mathrm{m}$ filters) released by the destruction of bacteria by sonication of a natural seawater sample consisted of enzymes bound to bacterial cell-wall fractions. Those enzymes obviously remained active after the destruction of the organism. Therefore, microbial cell-wall fractions originating from either viral lysis or the egestion of protozoan food vacuoles constitute submicronic particles of a special kind. These particles are appropriate hosts for extracellular enzymes. Nagata \& Kirchman (1992) found that digestive enzymes released by flagellate grazing activities were embedded in cellwall-like structures, suggesting an incomplete digestion of bacterial cell walls by phagotrophic flagellates. Specific protozoan digestive enzymes that could clearly be distinguished from bacterial prey mediated enzymes have been found by González et al. (1993) and Vrba et al. (1993). Those enzymes, however, had $\mathrm{pH}$ optima clearly different from the $\mathrm{pH}$ of natural sea water.

Our results show that the occurrence of free aminopeptidase, as estimated using fluorogenic substrate analogs, can be greatly enhanced by growth of phagotrophic nanoflagellates on bacterial prey (Figs. 3C \& 4C). Indeed, in experiments with phagotrophic flagellates grown on either live (FL) or heatkilled bacteria (FHK), free aminopeptidase activity accumulated in the culture medium, reaching $>80 \%$ of total aminopeptidase activity at the end of the experiments. However, the $\alpha$-glucosidase activity remained at similarly low proportions compared to total $\alpha$-glucosidase activity in all our assays, regardless of flagellate presence. As shown in FHK, the protozoan release of free aminopeptidase can not simply be attributed to the enzymes bound to undigested bacterial cell walls (as discussed above), since the bacterial prey had been inactivated by heat. In both FL and FHK, maximum increase of free aminopeptidase EEA was obviously coupled to flagellate growth, while continuing after the breakdown of the flagellate biomass (Figs. 3C \& 4C). Free aminopeptidase in filtered seawater samples seems to be stable over time scales of weeks (Karner \& Herndl unpubl.). The free enzyme activity could, therefore, remain present even if enzyme expression already ceased. For this reason, free enzyme expression can not reasonably be computed on a cell or biovolume basis, as presented for particle-bound EEA in Table 1.

On the other hand, in our BO and BE experiments (flagellate-free cultures of mixtures of naturally occurring marine bacteria), comparatively low amounts of free $\alpha$-glucosidase and free aminopeptidase EEA were detected (Figs. 1B, C \& 2B,C). Bacterial lysis by virus infection may have occurred in our assays since viruses seem to be a normal part of the marine environment (Proctor \& Fuhrman 1990, Cochlan et al. 1993). However, relative stabilization or occasional decreases in bacterial abundances such as observed in BO and BE, respectively (Figs. $1 \mathrm{~A} \& 2 \mathrm{~A}$ ), did not lead to any significant release of free enzymes (Figs. $1 B, C \& 2 B, C$ ). We thus found no indication towards occurrence of free enzymes via possible virus-mediated bacterial mortality. Free EEA in $\mathrm{BO}$ and $\mathrm{BE}$ rather represented a background. Indeed in both $\mathrm{BO}$ and $\mathrm{BE}$ after Day 4 (start of the growth phase), variations of free EEA were about 6 -fold, whereas those for particle-bound EEA were about 40 -fold. Although bacterial populations, culture media, enrichment and resulting bacterial biomasses obtained in $\mathrm{BO}$ and $\mathrm{BE}$ were markedly different, proportions of free enzymes and maximum specific particle-bound EEA in both experiments were similar.

The FHK experiment shows that phagotrophic nanoflagellates may express cell-wall bound $\alpha$-glucosidase and aminopeptidase EEA. Flagellates inoculated upon heat-killed bacterial suspensions used in EEA measurements had already been grown for several generations upon the same heat-killed prey. Furthermore, in FHK, bacterial biomass did not recover after the breakdown of the flagellate peak (Fig. 4A). It has been demonstrated that phagotrophic flagellates selectively graze on live bacteria if present among inactivated bacteria (Landry et al. 1991). Therefore, possible contaminations by live bacteria in the FHK assays are likely to have been eliminated quickly. This rules out the presence of any significant amount of live bacteria in the FHK assays. It becomes therefore obvious that high EEA in FHK stems from phagotrophic nanoflagellates. When expressed on an average biovolume basis, flagellate-specific EEA is of a similar magnitude as bacteria-specific EEA for $\alpha$-glucosidase, and is up to 9 times higher for aminopeptidase (Table 1). Those possible relationships must certainly depend very much on species composition and changing cell morphologies of both bacteria and nanoflagellates, as well as on environmental parameters. In Table 1, the wide ranges within each assay and the differences between bacterial cultures of different origin and enrichment demonstrate this potential variability in biovolume-specific EEA. Protozoan EEA might have also been underestimated through the use of fluorogenic substrates in concentrations that saturate bacterial enzymes. Protozoan enzymes might have higher saturation levels than those assumed here.

Although EEA has been thought to be mainly bound to the cell walls of bacteria (see above), dissolved enzymes are thought to play a significant role in organic particle hydrolysis (Azam \& Smith 1991, Smith 
et al. 1992) and thus in $C$ and $N$ cycling. In the context of particle degradation, free enzymes were thought to be excreted by particle-attached bacteria. It has been hypothesized that particle decomposition during the organic matter downward flux could be explained by the requirements of bulk-phase bacterial production (Cho \& Azam 1988) rather than by secondary production by colonizing bacteria (Karl et al. 1988). Karner \& Herndl (1992) found that in marine snow samples, the proportion of free to total EEA was significantly higher than in samples of bulk-phase seawater. Smith et al. (1992) found a significant release of hydrolysis products from marine snow towards bulk-phase sea water, a possible supply route fuelling bulk-phase bacterial production. However, experimental results of G. Payet, M. Karner \& F. Rassoulzadegan (unpubl.) cast doubts on the assumption that bacteria respond to loads of organic particles by increasing the release of diffusible enzymes. In the light of our findings, both high enzyme activity in marine snow and its high proportion of free enzymes could be rather a result of an enhanced protozoan grazing activity. Indeed, bacterial grazers have abundantly been found on organic macroaggregates. Herndl \& Peduzzi (1988) reported that heterotrophic flagellate biomass was up to 3 times higher than bacterial biomass in marine snow samples. As we show here, biovolume-specific particle-bound EEA is of similar magnitude for bacteria and phagotrophic nanoflagellates. In ecological situations such as the above organic aggregates (marine snow), where the biomasses of bacteria and protozoa are similar, protozoanmediated EEA (both grazing-related free enzyme release and cell-wall bound enzymes) could be higher than bacteria-mediated EEA. Our results suggest that the protozoan community might be largely responsible for particle degradation through enzyme-catalyzed hydrolysis. The 'hyperproduction of enzymes' on organic aggregates (Cho \& Azam 1988) could then emanate from protozoan-mediated free and particlebound EEA, along with the action of particle-attached bacteria

In conclusion, we have provided evidence suggesting that phagotrophic flagellates are partially responsible for both free and particle-bound aminopeptidase EEA as well as for particle-bound $\alpha$-glucosidase EEA as measured at natural $\mathrm{pH}$ in marine environments. Free aminopeptidase seems to accumulate during flagellate grazing and as a by-product of flagellate decay. This finding is supported by experiments with heatkilled bacteria. No evidence was found for release of free enzymes via bacterial mortality or decay. The studied enzymes are ubiquitous in marine environments and were previously thought to be of mainly bacterial origin. As hydrolysis of carbohydrate and peptidic polymers (presumably by enzymes cleaving the fluorogenic substrates used in this study) represents a key parameter in the cycling of carbon and nitrogen, focus on protozoan related enzyme pathways is recommended in further studies

Acknowledgements. We thank A. Morel and M. Babin for providing labtime on the spectrofluorimeter. Special thanks to B. Avril for sampling offshore waters and to G. Payet for valuable help in experimental work on the BE cultures. We gratefully acknowledge the useful comments of 3 anonymous reviewers. As a part of the Ph.D. program by M.K. (University Pierre \& Marie Curie, Paris VI), this research is a contribution of the 'Ecologie du microzooplancton marin' team and was supported by the Commission of the European Communities (Bursary Contract B/SC1 $/ 915168$ to M.K. and MAST II CT930063 Mediterranean Targeted Program, sub-program Medipelagos) as well as by the CNRS/INSU (URA 716).

\section{LITERATURE CITED}

Azam, F., Smith, D. C. (1991). Bacterial influence on the variability in the ocean's biogeochemical state: a mechanistic view. In: Demers, S. (ed.) Particle analysis in oceanography. Springer, Berlin, p. 213-236

Cho, B. C., Azam, F. (1988). Major role of bacteria in biogeochemical fluxes in the ocean's interior. Nature 332 : $441-443$

Chróst, R. J. (1990). Microbial ectoenzymes in aquatic environments. In: Overbeck, J., Chróst, R. J. (eds.) Aquatic microbial ecology. Biochemical and molecular approaches. Springer, New York, p. 47-78

Chróst, R. J., Münster, U., Rai, H., Albrecht, D., Witzel, P. K., Overbeck, J. (1989). Photosynthetic production and exoenzymatic degradation of organic matter in the euphotic zone of a eutrophic lake. J. Plankton Res. 11 223-242

Cochlan, W. P., Wikner, J., Steward, G. F., Smith, D. C., Azam, F. (1993). Spatial distribution of viruses, bacteria and chlorophyll a in neritic, oceanic and estuarine environments. Mar. Ecol. Prog. Ser. 92: 77-87

Ferrier-Pagès, C., Rassoulzadegan, F. (1994). Seasonal impact of the microzooplankton on pico- and nanoplankton growth rates in the northwest Mediterranean Sea. Mar. Ecol. Prog. Ser 108: 283-294

González, J. M., Sherr, B. F., Sherr, E. B. (1993). Digestive enzyme activity as a quantitative measure of protistan grazing: the acid lysozyme assay for bacterivory. Mar. Ecol. Prog. Ser. 100: 197-206

Herndl, G. J., Peduzzi, P. (1988). Ecology of amorphous aggregations (marine snow) in the Northern Adriatic Sea: I. General considerations. P.S.Z.N. I: Mar. Ecol. 9: 79-90

Hollibaugh, J. T., Azam, F. (1983). Microbial degradation of dissolved proteins in seawater. Limnol. Oceanogr. 28; $1104-1116$

Hoppe, H.-G. (1983). Significance of exoenzymatic activities in the ecology of brackish water: measurements by means of methylumbelliferyl-substrates, Mar. Ecol. Prog. Ser. 11: 299-308

Hoppe, H. G. (1991). Microbial extracellular enzyme activity: a new key parameter in aquatic ecology. In: Chróst, R. J. (ed.) Microbial ectoenzymes in aquatic environments. Springer, New York, p. 60-82

Hoppe, H.-G., Kim, S.-J., Gocke, K. (1988), Microbial decomposition in aquatic environments: combined process of 
extracellular enzyme activity and substrate uptake. Appl. environ. Microbiol. 54: 784-790

Isao, K., Hara, S., Terauchi, K., Kogure, K. (1990). Role of sub-micrometre particles in the ocean. Nature 345 : $242-244$

Karl, D. M., Knauer, G. A., Martin, J. H. (1988). Downward flux of particulate organic matter in the ocean: a particle decomposition paradox. Nature 332: 438-441

Karner, M., Herndl, G. J. (1992). Extracellular enzymatic activity and secondary production in free-living and marine-snow-associated bacteria. Mar. Biol. 113: 341-347

Landry, M. R., Lehner-Fournier, J. M., Sundstrom, J. A., Fagerness, V. L., Selph, K. E. (1991). Discrimination between living and heat-killed prey by a marine zooflagellate, Paraphysomonas vestita (Stokes). J. exp. mar. Biol. Ecol. 146: 139-151

Nagata, T., Kirchman, D. L. (1992). Release of macromolecular organic complexes by heterotrophic marine flagellates. Mar. Ecol. Prog. Ser. 83: 233-240

Porter, K., Feig, Y. S. (1980). The use of DAPI for identifying and counting aquatic microflora. Limnol. Oceanogr. 25: $943-948$

Proctor, L. M., Fuhrman, J. A. (1990). Viral mortality of marine bacteria and cyanobacteria. Nature 343: 60-62

This article was submitted to the editor
Rivier, A., Brownlee, D. C., Sheldon, R. W., Rassoulzadegan, F. (1985). Growth of microzooplankton: a comparative study of bacterivorous zooflagellates and ciliates. Mar. microb. Food Webs 1. 51-60

Rosso, A. L., Azam, F. (1987). Proteolytic activity in coastal oceanic waters: depth distribution and relationship to bacterial populations. Mar. Ecol. Prog. Ser. 41: 231-240

Smith, D. C., Simon, M. Alldredge, A. L., Azam, F. (1992). Intense hydrolytic enzyme activity on marine aggregates and implications for rapid particle dissolution. Nature 359: $139-142$

Somville, M. (1984). Measurement and study of substrate specificity of exoglucosidase activity in eutrophic water. Appl. environ. Microbiol. 48: 1181-1185

Somville, M., Billen, G. (1983). A method for determining exoproteolytic activity in natural waters. Limnol. Oceanogr. 28(1): 190-193

Vives Rego, J., Billen, G., Fontigny, A., Somville, M. (1985). Free and attached proteolytic activity in water environments. Mar. Ecol. Prog. Ser. 21: 245-249

Vrba, J., Simek, K., Nedoma, J., Hartman, P. (1993). 4-methylumbelliferyl- $\beta-\mathrm{N}$-acetylglucosaminide hydrolysis by a high-affinity enzyme, a putative marker of protozoan bacterivory. Appl environ. Microbiol. 59(9): 3091-3101

Manuscript first received: January 25, 1994

Revised version accepted: September 16, 1994 